\title{
BLACK SEA SECURITY: THE ROMANIAN PERSPECTIVE NATO- EU INTEROPERABILITY, A DIVION OF LABOUR
}

\author{
Olga Raluca CHIRIAC \\ Department of International Relations and European Integration \\ National University of Political Studies and Public Administration \\ Bucharest/Romania
}

\begin{abstract}
The current world order is under scrutiny. The 2014 illegal annexation of Crimea and the conflict in Eastern Ukraine have marked a turning point in international affairs: a state actor used force against another sovereign state to gain a territorial victory in order to advance its own geopolitical interests. Since then all major building blocks of the system, mainly the multilateral institutions such as the UN and NATO have been scrutinized and their effectiveness has been questioned. The significance of the individual nation state is gaining again in significance. It is more important than ever to find ways to repair transatlantic discord and to deepen cooperation between NATO and the EU, to recalibrate the strategic bedrock of the alliance and to reposition the transatlantic defence community in a way that facilitates effective defence and deterrence.

It is the aim of the article to define and contextualize the Romanian official strategic vision and to outline how it in fact successfully synergies its membership in NATO and in the EU with bilateral partnerships in order to achieve its strategic goals as well as to contribute to the transatlantic cause.

The paper starts by introducing the theoretical framework, mainly structural realism. Next, it defines the Romanian strategic view, it contextualizes it and it correlates the strategic priorities to the Black Sea area. The article focuses on EU NATO complementarity through a Romanian strategic lens by focusing on interoperability and crisis readiness in the Black Sea, an area of existential
\end{abstract}


significance to the Romanian national interest. Finally, the conclusions underscore how the Romanian strategic paradigm creates an auspicious medium in order for NATO - EU complementarity and deeper cooperation to occur.

Keywords: Black Sea Security; Interoperability; NATO; PeSCo; Romania.

\section{INTRODUCTION}

2020 is shaping to be a year which the international community could not rally have planned for. In 2014, the illegal annexation of the Crimean peninsula by the Russian Federation signaled a new phase in the global system, but not many anticipated that a global health crisis will happen and place a magnifying glass on all vulnerabilities of each state individually as well as of the international system as a whole. In this system, regional actors gain in importance, regional powers become more capable of driving change with global implications. The institutions of the world order exist, they function and they will most likely not go anywhere in the short to medium term, but some have their relevance questioned, some are still working on redefining their raison d'etre, others are under attack by divisive forces such as populism. The article is looking to take an in depth look at the relation between two such institutions, mainly NATO and the European Union, and is setting to do this through the lens of one state, the Republic of Romania.

In 1957, Belgium, France, Italy, Luxembourg, the Netherlands, and West Germany signed the Treaty of Rome, the "Treaty on the Functioning of the European Union" which marked the creation of the European Economic Community (EEC). The same treaty established the European Commission. The foundations of the European Union were laid in Rome. The Maastricht Treaty of 1992 removed the word "economic" from the Treaty of Rome's official title and the Treaty of Lisbon in 2009 renamed it the "Treaty on the Functioning of the European Union". The removal was not a simple name change it transcended into the essence of the EU: now a complex project meant to consolidate the 
member states into an economic as well as political power. The end of the Cold War enabled the countries that were part of the Eastern Block to join the EU one by one and, finally, Brexit brought the withdrawal of the United Kingdom from union. The EU today: twenty-seven countries, all under the EU flag, looking for deeper multilevel integration. The EU is also in search of its identity as a credible security provider for its own members as well as a solid security and defence player in the international system. After many geopolitical shifts and political events, most notably the previously mentioned annexation of Crimea by the Russian Federation in 2014, these 27 members find themselves confronted with divergent visions in several key domains.

One of the EU tools in addressing the security and defence debate is PeSCo: the Permanent Structured Cooperation framework, a structure that permits willing participating member states deeper cooperation in the sector. European defence cooperation once again at the top of the agenda in Brussels, deliverables however are in the hands of members states. Viewed as mainly a FrancoGerman led initiative in the beginning stages, it morphed into a realistic opportunity for all participants to leverage EU membership in the context of defence. The EU is in search of a "phased approach toward capability and operational commitments as a way to increase Europe's general defense effort." (Billon-Galland 2017, 1). One of the challenges in reaching a consensus, in any area as a matter of fact, is the diverse make up of the members states: the different strategic cultures, varying political and societal attitudes, historical experiences and economic status. Each country has its own security policy, national interests, economic agenda. Yes, some states are closer to each other than others geopolitically or culturally, and some assume a more senior, leadership role, but at the end of the day, the perspective of each should be analysed and understood, otherwise the final goal of a cohesive defence community acting as one in the interest of the greater good would essentially be most difficult to reach, if not impossible.

Romania's road to EU membership was by no means easy, nor was it short, but after decades of communism and a period of transition in the 90s, after economic, political and military reforms, Romania finally became a member state in 2007. 
It is the hypothesis of the paper that the Romanian strategic approach in general and in the Black Sea in particular is an example of how the NATO-EU security and defence relationship is complementary with no divergent elements. The paper focuses on the interrelationship between NATO and the EU in the PeSCo framework as the Romanians have seen fit to integrate them into their defence architecture.

The research questions will analyse what the Romanian Security approach actually looks like, what pillars it is built on, how these pillars interplay with each other in Romanian strategic planning. The basis of the analysis is the Romanian-NATO-EU/PeSCo triad with a particular emphasis on the Black Sea due to the important role the Black Sea area plays in Romanian security concept and in the Romanian strategic approach. Finally, the article will underline the most significant assertion that Romania views the NATO-EU relationship as division of labour, not competing, with the aim of optimizing defence capabilities, security planning and strategic posture.

"An Inquiry into the Nature and Causes of the Wealth of Nations" by Adam Smith starts with a simple sentence which essentially synthesizes the entire premise of the present article, mainly that NATO and the EU in the PeSCo framework can through division of labour strengthen each other and their member states: "The greatest improvement in the productive powers of labour, and the greater part of the skill, dexterity, and judgment with which it is anywhere directed, or applied, seem to have been the effects of the division of labour" (Adam Smith 2007, G.ed.14)

\section{A FRAMEWORK FOR ANALYSIS}

The paper approaches the discussion form a neorealist standpoint. The current global events could constitute a structural shift in the alignment the international system has grown into post WW II, the global pandemic forced the world to take drastic measures in a very short amount of time and this, among other things, put a magnifying lens on the weaknesses that were already eroding 
the status quo: the United States, the worlds still leading power confronted with internal divisions and a polarized political system, Europe fragmented by both Brexit and populism, a European Union in search of political leadership, tense, sometimes antagonistic Euro-Atlantic relations, exacerbated during the current presidency, an expansive China who's economy on the other hand depends heavenly on exports to the United States and the European Union, a militarily revisionist Russia held back by its energy dependent economy. By no means does this translate into the certainty that the current health crisis will decide the way things will be going forward, it only signals the necessity to reevaluate what so many call great power competition, to take a thorough look at allies and partners, maybe more than at competitors, to recalibrate priorities and goals. In pure neorealist stance, great power competition will become more intense, consequently corroding multilateralism and most likely leaving way for unilateralism.

The fundamental belief of neorealism is that power is the driving force in international relations. Leading structural realist John Mearsheimer synthesizes best the structural realist world view in which: "power is the currency of international politics. Great powers, the main actors in the realists' account, pay careful attention to how much economic and military power they have relative to each other" (Mearsheimer 2007, 72). Power in the current analysis refers to a state's capacity to produce the intended results in its pursuit of national interest. Great power competition is important because it affects all states in the system, including those who do not have enough economic or military clout to influence decisions globally. This is also the case of Romania. With a population of little over 19 million people and a Gross Domestic Product of 249.2 million USD in 2019 (World Bank 2020) Romania is a small power.

Romania is a participant in the current international world order and an active adherent to the multilateral institutions of the system. In the current global institutional governance setting Romania is a member of the North Atlantic Treaty Organization (NATO) since March 2004, of the European Union (EU) since January 2007, it joined the International Monetary Fund (IMF) and the World Bank in 1972, and is a founding member of the World Trade Organization (WTO). Finally: "Although Romania's desire to become part of the 
United Nations was formally stated back in 1946, our country's accession was blocked until 1955" (Romanian Ministry of Foreign Affairs 2020). Romania is a willing participant in the current global system of governance.

Structural realists believe that the international system is anarchical and that it is this anarchic structure that determines state behavior (Mearsheimer 2007). The essence of the anarchical system is twofold: first, there is no central authority governing the system and second, there is no world police force. What this means is that there is no central government tasked with providing laws, rules, norms and protection for the states, nor is there a world police to enforce these laws, rules and norms. The anarchical structure of the international system has direct consequences: states will be first and foremost focused on their survival. This will be the main driver behind state behavior. Cooperation is not completely discounted in this approach to international affairs, however, trust in the intentions of other states or, as a matter of fact, trust in any other stakeholder, is quite challenging and therefore cooperation potential is limited. Structural realists focus on a state's capabilities, both military and economic. The present analysis will, from this perspective, go on the assumption that all states in the system have some sort of offensive capability because each state "has the power to inflict some harm on its neighbor" (Mearsheimer 2007) and that all states act as rational actors. It has not been more evident than in the way states have first reacted to the global health crisis that indeed the main driver in state behavior remains self-preservation and capability dominance. Rationality in state behavior means states function with the constant awareness of their external environment and that a significant amount of resources is employed in order to establish successful ways to survive it. The current pandemic is for instance a stressor that is putting tension on the structure of the international system, because each state is feeling threatened and is doing everything it deems necessary to survive. States can be democracies or authoritarian states, therefore the measures they take to survive the global health crisis or any other crisis differ, however, they all have the same goal: survival. The end is the same, the means differ. It remains to be seen whether the current situation will strengthen or weaken this realist tenant. Driven by the individual need to intervene and survive, to self-help, it will probably strengthen it. 
After establishing that the unit of analysis is the nation state, such as Romania and that states function in an anarchical international system, it is important to establish how states achieve their ultimate goal: survival, pursuit of national interest. The answer is grand strategy.

Grand strategy may be defined as the blueprint employed "to secure and advance a nation's long-term, enduring, core interests over time" (Joint Doctrine Note 1-18 2018, vi). Grand Strategy synergies the military political, economic, diplomatic means available to the state to achieve the desired ends, defend the national interest.

The current analysis is focused on the Romanian perspective and grand strategy: Romania in the global spectrum, Romania the European actor and Romania the regional actor in the Black Sea area. In keeping with the scope of the paper, this perspective will be analysed from the defence and security angle. What the paper is not looking to do is to evaluate the overall developments of grand strategy and power politics. The focus is Romania and Romania is pursuing its national interest rationally in the anarchic international system, it adheres to the institutional framework already established and accepted by the international community and she is doing it by pursuing its grand strategy. Within this strategic view, the defence strategy, bedrock of its grand strategy, is built upon what is perceived as threats. The main vector of Romanian national defence strategy is what Romanian leadership perceives as a threat to its national interest. This in turn leads to planning and building a strategy for the security and defence policy, and, finally, this materializes in how military capabilities are procured, deployed, leveraged.

The current literature on grand strategy and security strategy is very US centric (Acheson 1987; Art 2009; Kennedy 1989; Kissinger 1994; Mead 2007). US centric in a sense that it focuses on American Grand Strategy and that it also focuses on the states that the Americans consider competitors: Russia (Gibbs 1987; Luttwak 1983), China (Goldstein 2001; Johnston 1995; Luttwak 2012). Notably missing from the literature review is the European Union and that is because the EU is in fact a system of governance, a union of states, not a government on its own. The discussion around the EU Security and Defence Strategy is in fact built around this difference and it will probably remain so for the medium to long term. 
Whether the EU will eventually succeed in its pursuit of a grand strategy and be able to engage in the international system as a standalone, cohesive security actor on the world stage is not clear yet. The expectation for this is documented in the Lisbon Treaty (Art 2 TEU), however, the attainability of the end goals weighs heavily on each member state individually, on the Brussels bureaucracy, as well as on the evolution of the international structure globally. The Lisbon Treaty set the goal, the ultimate end, the means and the process remain fluid, meaning that the EU is in the process of building a process and procuring the means.

The methodology employed in order to conduct this multilevel, multidimensional evaluation will be based on official document review and discourse analysis. Document analysis was the first source of primary data pertinent to the research objective in the form of official security and defence documents, state reports, military and diplomatic reports. In addition to document analysis, a key source for data collection were speeches, interviews and official declarations of Romanian officials.

The present study intends to contribute to the literature on Romanian strategic view as a whole and to the conceptualizing of Romania as key security player in the Black Sea area, the southern half of the Eastern Flank of NATO. Furthermore, the article outlines a key aspect of Romanian defence: a policy which manages to successfully leverage NATO and EU membership, outlining that militarily and strategically, interoperability, troop mobility, educational interoperability are not only not jeopardizing NATO but absolutely necessary in order to facilitate an effective response to a continuously changing, complex and complicated contemporarily strategic environment. 


\section{CONTEXTUALIZING ROMANIAN SECURITY\& DEFENCE POLICY}

\subsection{Romanian Strategic Concept, Security Architecture, Defence Structure}

It is important to start by first defining how Romania constructed its security architecture as well as by placing the Romanian security concept in the global and regional context.

Ever sine 1989, during the post-communist period, regardless of who was sitting in Cotroceni Palace or who was the majority party in the Romanian Parliament, the country has remained consistent in one area of statehood: defence. The foundation of the Romanian Security Structure is built on three pillars: the strategic partnership with the United States, the North Atlantic Treaty Organization and the European Union.

The Romanian President, currently H.E Klaus Werner Iohannis, serves as the president of the Supreme National Defence Council (Consiliului Suprem de Apărare a Țării-CSAT). CSAT is an autonomous administrative authority tasked by the Romanian Constitution with the "organization and unitary coordination" of all activities pertaining to the defence and national security of the country. CSAT conducts its activity under parliamentary supervision. CSAT members include: the President, the Prime Minister, Defence Minister, Ministers of Internal Affairs, Foreign Affairs, Justice, Economy and Energy, and, Public Finances. The Council also includes the Directors of Romanian Intelligence Services: internal (Serviciul Român de Informații - SRI) as well as external (Serviciul de Informații Externe - SIE)(Romanian Presidency 2020).

The Romanian Armed Forces function under the authority of the Romanian Ministry of Defence (Ministerul Apărării Naționale- MApN) and they consist of land forces, air force, naval forces, special forces and the Medical Directorate. The Medical Directorate oversees: The Military University Emergency Hospital Dr. Carol Davila, the Cantacuzino National Medical Military Institute for Research and Development as well as the National Institute for Aeronautical and Space Medicine General doctor aviator Victor Anastasiu (MApN 2020) The Romanian Armed Forces have their own Intelligence Group under the 
leadership of the Defence Intelligence General Directorate. Finally, the Roman Ministry of National Defence has a Directorate for the Prevention and Investigation of Corruption and Fraud, an arm of the defence ministry that is singular of its kind in the EU. Conscription in the Romanian Armed Forces was abolished in 2006 and military personnel became voluntary career soldiers and officers (MApN 2020).

The overarching strategic direction of Romanian Defence is clearly expressed in the Romanian Defence Strategy: "Romanian National Defence Strategy 20202024: Together for a Safe and Prosperous Romania in a World Marked by New Challenges" which conceptualizes security as it was defined in the previous Defence Strategy: "Modern Armed Forces for a Powerful Romania within Europe and Around the World" denoting continuity and consistency. The overall approach to national security is described as "extended", which according to the 2016 document means defence is "merged and mutually balanced with the dimensions of law enforcement, intelligence, counterintelligence and security, diplomacy, crisis management, education, health, economy, energy, and demographics" (Romanian Defence Strategy 2016, 14). The 2020 security document emphasizes the necessity for Romania to build up a high degree of "strategic credibility" by strengthening state and societal resilience, government institutions and the triad: government-state institutionscitizen. Romania remains firmly committed to the transatlantic path it is engaged on since the end of the Cold War and it continues to define its Foreign and Defence Policies through three dimensions: EU membership, NATO membership and the Strategic Partnership with the USA (Romanian Defence Strategy 2020).

Romania reaffirms its commitment to European values, to the rule of law, to democracy and to an independent judiciary. Abroad, Romania sees itself as a pillar of regional security, especially in the Black Sea Region, a committed partner to the United States as well as to European allies. The emphasis of the new document is put on Romania's stabilizing role in the region in general and in the Black Sea in particular and this holds a lot of value in the current international context. At a global level, great power competition realigns the priority regions of the great powers and resources are being reallocated to 
different area like the South China Sea. The Black Sea has always played an important role in the Romanian strategic approach and, since it basically represents the southern half of the NATO Eastern Flank, it warrants a more attentive discussion in the EU realm. Interoperability in the context of NATO, EU or both, is mentioned seven times in the new Romanian National Defence Strategy. It does look as the current administration is acutely aware that alliances and partnerships can only do so much in times of crisis if the military systems are not integrated properly and troops and equipment cannot be transported timely and efficiently. This is an angle that weighs heavily on the Romanian government since in spite of being an EU member state since 2007, with the same access to European funds as any other member state, Romania has so far done poorly in infrastructure consolidation and modernization. Poor conditions of roads and railways, outdated airports and shipyards make Romania, therefore NATO, as well as the EU, the security actor, vulnerable. Strategic credibility leads to the power to deter and deterrence is key in the Black Sea both to Romania and NATO.

After the 2014 illegal annexation of Crimea by the Russian Federation, Romania insisted that additional NATO forces be temporarily stationed on Romanian territory. This led in 2015 to the establishment of a Multinational Division under Romanian command with HQ in Bucharest (NFIU 2020). The NATO Force Integration Unit Romania works actively on the alliance's collective defense planning and focuses on the deployment of NATO forces to Romania in times of crisis (NATO 2020). While important, these efforts are not enough since armed forces need to be quickly deployable in times of crisis and supported by sound infrastructure, both civilian and military, and efficient logistics. Infrastructure, "a term generally applicable for all fixed and permanent installations, fabrications, or facilities for the support and control of military forces" (NATO 2020), has been a challenge for the Romanians, especially since the end of the Cold War, when neither government have done anything to maintain and improve infrastructure. Participation in PEsCO projects can streamline efforts for improving infrasturture and allow for more oversight as well as accountability. A framework such as PeSCo is viewed in a positive light by Romanian leadership also because it can facilitate access to EDF funds with in 
turn could partly solve funding shortages. A good example of leveraging alliances and partnerships for the benefit of all sides, not in the PeSCo framework, but in the NATO dimension is NATO's land-based missile defense system in southern Romania at Deveselu, Craiova County. In 2010, Romania agreed to become the host nation for part of a NATO missile defence system, the other half being stationed in Poland. The system became operational in 2016 with 24 SM-3 missiles being housed at the Deveselu Airbase (US Embassy, Romania 2020). This has brought to Romania American technology and troops and with them work on local infrastructure and access roads.

The global health crisis will most likely present a serious challenge to the Romanian economy as much as it in fact does for all other states in the international system, but Cotroceni shows intentions for accelerated reform in the next four years. The Romanian Ministry of Defence Budget plans designate armed forces modernization and building up adaptability as one of the top three strategic priorities of the country in the medium term, meaning for the period 2020 to 2023 (MApN 2020). It is up to the political arm to execute the plans and facilitate funding to the Romanian armed forces.

The Romanian security concept is multi-dimensional, rooted in a strong bond between society, prosperity, the rule of law, democracy and identity. Romania is positioned very well in order to claim a pivotal security role in the region.

Romania, similarly to its European allies, believes that the illegal annexation of Crimea signaled a necessary change in expectations vis-a-vis a potential military conflict on the continent. In the shadow of its own history, Eastern states fear military as well as non-kinetic aggression such as destabilizing influence campaigns on the Eastern Flank far more than their Western counterparts. The EU remains in the beginning stages of planning and implementing a cohesive defence policy, other security institutions are relied on for this and NATO remains the main security facilitator: " The EU will step up its contribution to Europe's collective security, working closely with its partners, beginning with NATO" (EU Security Strategy 2016).

Romanian defense policy of 2015 identifies Russian assertiveness, "increased by the presence of Anti-Access/Area Denial (A2/AD) capabilities in the Black Sea" as "the main threat against the security of Romania and other states in the 
region". (Romanian Security Strategy 2015, 12) The 2015 Romanian leading official defence document asserts that the strategic goal can only be achieved if capabilities and logistics improve in order to be prepared to defend Romanian national interest. The 2020 Security Policy continues along these lines and emphasizes the importance of Romania for the Eastern Flank of the North Atlantic Alliance as well as the strategic significance of the Black Sea Area in the context of the increased efforts by the Russian Federation to build up the naval presence as well as the militarization of the Crimean Peninsula. Interoperability is clearly named as a necessity and priority to Romania.

During President Iohannis's visit to the Whitehouse in August last year, military cooperation and energy security were at the top of the agenda. Both President Iohannis and President Donald Trump reiterated the two major front liners of the Romanian American Strategic Partnership, hence of the Romanian strategic vision: "As the Presidents of the United States and Romania, we stand together as friends and Allies to advance our robust and durable strategic partnership" (White House 2019). The Joint Declaration released by the White House stresses key bilateral priorities: modernization of the armed force, meeting NATO burden-sharing commitments, bolstering defence and deterrence posture on NATO's Eastern Flank, including in the Black Sea, law enforcement and anticorruption partnership, and, trade growth between the two countries.

The second pillar of Romanian security architecture and of fundamental significance to the strategic view is NATO membership. Post Crimea NATO, an alliance in search of redefining its goals post Cold War, more vocally returned to its roots with a narrow focus on collective defence and deterrence, on improving its ability to protect its frostlines at short notice. The annexation showed that treaties can be broken, state boundaries crossed, force, hard power, used by a state actor to achieve its goals. The actions of the Russian Federation managed to recalibrate the alliance on the principle that helped create it in the first place: collective defence. The words of then US Secretary of State Madeleine Albright in her statement to the North Atlantic Council in Brussels, Belgium, in December 1998 echo back in time and more relevant than they ever were: "I view NATO's future role in that broader partnership as the institution of choice when North America and Europe must act together militarily" (US DoS 1998). 
The third dimension of the Romanian strategic view is the membership in the European Union. That being said, in order to understand its role in the Romanian strategic view, this third pillar needs to be looked at from a different perspective than NATO and the Strategic Partnership with the US. While the first two are direct providers of security for Romania, the third one does it indirectly as related to armed forces and capabilities. This assertion stems from the fundamental difference between the two institutions. While NATO was, is and will remain a military organization and a security and defence institution, the European Union has its roots tied to economic aims. One was born as a military alliance with military considerations, the other originates out of the desire to build a unified market with easy customs procedures and an easier flow of goods and services. The debate over how the EU will define its role as a security and defence actor is still in the beginning stages and that is not to say that with time it will be able to clarify its defence vision, however the union is not there yet. In the case of Romania, just like with all other member states, the EU provides security mostly through the economic dimension. The difference within EU approaches becomes evident in how some states engage the Russian Federation as well as the Republic of China. While for example Germany and Austria view Russia as an economic partner, Poland and Romania consistently voice concerns. British foreign secretary, Jeremy Hunt, shared these concerns in a statement referencing the NordStream 2 pipeline project: "There is a contradiction between asking America to spend more as a proportion of GDP on defense and contributing to NATO and, at the same time, doing an economic deal with Russia that is going to mean Russia is richer and more able to spend money on weapons that could potentially be used in an offensive way" (Deutsche Welle). Similarly, when referencing a potential European army, Dutch Prime Minister Mark Rutte voiced concerns back in 2018 when he expressed his governments perspective on NATO at the European Leaders Summit in Brussels: "The idea of a European Army goes way too far for the Netherlands" he said after a cabinet meeting. "NATO is and remains the cornerstone of our defense policy" (Thomson Reuters 2018).

Simply put, for Romania in the security/defence dimension, EU plays a more diminished role due to the nature of how the EU is constructed and how its 
purpose is defined by key decision makers in Bruxelles. Obviously, the EU is in fact a project in continuous transformation mode, it has fluidity, therefore, it could very well become a defence powerhouse, however this depends on too many stakeholders and too many political decision makers with different political agendas. The difference in vision, the complexity of state sovereignty, drive the diminished role purely through the nature of the structural makeup not because Romania is in any way holding back from a deeper security cooperation.

The standout positive takeaway is that the EU is actively engaging in internal dialogue and, at the end of the day, initiatives such as PeSCo, granted there is consistency and follow through in implementation, can lead to a better mutual understanding of threat perception and to a cohesive, strong, applicable vision.

\subsection{Romania on Strategic Autonomy}

The discussion about political synergy in Bruxelles as it applies to security and defence leads to the often misinterpreted concept of European strategic autonomy. European army, strategic autonomy, europeanization, all are in no way novel terms in EU circles. 'Strategic autonomy' as mentioned in the $2016 \mathrm{EU}$ Global Strategy has been a widely debated goal and quite many European politicians and commentators have been propagating the idea that the US government is completely opposed to it because it would undermine NATO and jeopardize the alliance. There is a very significant difference in what practitioners understand as autonomy in contrast to politicians and commentators. Militarily speaking, strategic autonomy and interoperability are terms that can only bolster transatlantic defence capabilities and the US has in fact been a longstanding proponent of Europeans doing more for providing their own security then they are at this time. If there was a moment in time when this was more obvious, it is now, during a global health pandemic. One of the first and most significant victims of the pandemic in the EU was the budget allocated to defence spending. Under tremendous pressure to try to efficiently fight the virus as well as its effect on the economy, Brussels and individual member states alike were forced to reallocate a large majority of the financial 
resources to sectors other than defence. Europe was supposed to embark on a long-term process designed to deepen defence and security cooperation between EU member states, furthermore, interoperability of independent capabilities was supposed to be a priority. In the case of Romania, interoperability and capabilities reform is still a priority as outlined in the National Defence Strategy, however, just like in the overarching EU framework, funding remains a challenge.

Washington has actually been pushing for more European involvement, for quite a while, far beyond the current administration. For instance, the $2 \%$ commitment is all about the European active engagement with the alliance and logistical autonomy would also be a concrete show of commitment and reciprocity. In the current global context, when the US is looking to invest more and more resources in other parts of the world, America wants and needs to have a militarily committed as well as credible ally in the European Union.

In the PeSCo context, it is the European Defence Fund (EDF) in particular that has indeed drawn criticism from across the Atlantic with regard to the proposed conditions for "third-party states" participation which are viewed as very limiting and therefore a negative for the US defense industry: "poison pills" meant to "effectively preclude participation by any company that uses U.S.origin technology." (Reuters 2019). From the perspective of the Romanian Ministry of Defence the European Defence Fund is nothing more than a financial tool in support of European capability development. It is unclear still how the Romanians will leverage access to the European Defense Fund incentives in order to modernize their defence capabilities and infrastructure.

In the Romanian view, strategic autonomy means simply autonomy to decide with regards to defence not a standalone European Army. Romania fully supports the cohesive European Security and Defense policy which is in the beginning stages of its existence, however, in its interpretation, it does not mean a strategic delink from the US and NATO. The Romanians are not influential enough in Brussels and do not posses the strongest economy in the union, their national interest is fundamentally threatened by both territorial aggression of their eastern neighbors as well as propaganda operations. 
In light of the current global health pandemic, it is becoming more and more less likely that the EU will continue to pay the same attention to defence and security in the traditional sense. At this time, the West has to remain united and, not to ignore, the West must optimize all resources: military, technological know how, economic, human. Only together can the West surpass this challenge. This view is articulated in the most recent Romanian Defence Strategy several times.

Strategic autonomy as European citizenship and responsibility for a more selfaware European defence community, that is something that Romania has tried to achieve. Romania has honored the NATO commitment of $2 \%$ and all security documents like the Romanian Military Strategy and the Romanian White Paper map out specific plans to invest in military capabilities, infrastructure and human resources. This is an angel that in the Romanian view would not jeopardize the strategic partnership with the US or the success of NATO which to this day is the major guarantor of security in Europe. Concerns the United States will gradually retreat from Europe have so far been unfounded. What could happen is that the US could deploy more resources in the East versus the traditional West, but this is also relatively unlikely, at least in the near future, when the Americans have to worry about Asia, the Middle East and internal challenges generated by political polarization and the health crisis. That being said, nothing can guarantee if potential military retreat from the EU space could indeed happen or not. After all, states are rational actors, interacting with each other in an anarchic system and motivated by their own self interest.

\section{BLACK SEA SECURITY: THE ROMANIAN PERSPECTIVE - NATO - PeSCo COMPLEMENTARITY}

4.1 PeSCo: What it is and what it is not.

Permanent Structured Cooperation (PeSCo) is a component of the European Union's Common Security and Defense Policy (CSDP). It was activated in 2017 and it is meant to streamline an integrated European approach to defence and security. The initial steps towards PeSCo were made by the United Kingdom 
and France in 1998 with the Joint Declaration on European Defence by proposing increased spending for EU's defence budget and military capabilities. The declaration marked an important point on the path to institutionalizing European defence by facilitating the concentration under the same umbrella of all efforts made by states in this domain. The initial response to the FrancoBritish St Malo Declaration was met with reluctance by other member states and it only materialized with Brexit in 2017. It was ironically the United Kingdom who was hesitant towards PeSCo, this out of concerns about duplicating efforts or undermining NATO. Once the UK voted on leaving the EU, the road was cleared to more actively engage in initiating concrete steps towards the materialization of the cooperation framework. The Permanent Structured Cooperation is not an EU institution, but a framework in which defence projects are developed, proposed and implemented by the armed forces of participating member states. PeSCo is the EU mechanism aimed to facilitate deeper defence cooperation between willing member states through projects and concrete commitments. Participation in PeSCo projects is voluntary, however, once committed, it becomes binding. Together with the Coordinated Annual Review on Defense (CARD), the European Defense Fund and the Military Planning and Conduct Capability (MPCC) it forms the bedrock of European Union defence structure. PeSCo has a two level structure: the Council level and the Project level. Each project is developed, managed and run individually by the participating states. In turn, the Council is responsible for the overall policy direction and for the evaluation of whether each member state is fulfilling requirements (PeSCo 2020). Decisions are reached by unanimity rule. Funding for each project comes from participating states as well as from incentives by the EDF. Participating countries can be asked to leave PeSCo in the event it is concluded that commitments were not met.

At the global level, the European Union and its mechanisms, such as PeSCo, constitute one side of the foundations of the world order built after WW II. In the wake of opportunistic powers looking to assert more and more influence in the international system, the PeSCo framework gains in significance because it is aimed at giving the EU the integrated defence structures to do that. 
Romania is a participant in several PeSCO projects: EU Training Mission Competence Centre, Helicopter Hot and High Training(H3 Training), CBRN Defense Training Range, EU Network of Driving Centers, Maritime (Semi-) Autonomous Systems for Mine Countermeasures, Deployable Modular Underwater Intervention Capability Package, European Medical Command, Military Mobility, Geo-Meteorological and Oceanographic Support Coordination Element, Materials and Components for Technological EU Competitiveness(MAC-EU), EU Collaborative Warfare Capabilities(ECOWAR), European Global RPAS Insertion Architecture System and, finally, Cyber Rapid Response Teams and Mutual Assistance in Cyber Security. Romania chose to participate in projects aimed at deepening logistical integration, coordinating education and training, cyber security, enhancing military mobility and maritime projects. There is no Romanian participation as of yet in three of the operation domains: land, air and space. Land Forces and Air are domains that in the Romanian territory have a very NATO centered approach. Romanian is in effect a large portion of the southern part of the NATO Eastern Flank, therefore it is mandatory to be prepared for a territorial aggression or kinetic attack. That being said, the Permanent Structured Cooperation (PeSCo) is not a replacement for NATO, nor is it a step towards a European Army. PeSCo the EU framework is the European pillar of transatlantic security architecture not a competitor. PeSCo is a necessary framework that can facilitate the strengthening of EU's capabilities and capacity to address its own security challenges first and foremost. The NATO-EU, whether through PeSCo or not, is a complementary relationship, an indispensable strategic partnership.

\subsection{NATO's Role and Presence in The Black Sea - Romanian Perspective}

NATO has been an indispensable building block of the transatlantic security architecture in the Black Sea since1951 when the Protocol regarding Turkey's membership to NATO was signed October 17 (Turkish Foreign Ministry 2020). During the Cold War, the Black Sea was a relatively stable strategic environment, we could say strategically frozen, where the overarching balance of power in the international system was impeccably mirrored. The Black Sea 
region was at a standstill between the USSR, with its satellite states Romania and Bulgaria on one hand and the USA through NATO and Turkey on the other. Ironically, it is during the Cold War that the game changer in present day Black Sea, has its roots: under the leadership of Nikita Khrushchev and by administrative action of the Presidium of the Supreme Soviet of the Soviet Union, the Crimean Oblast was transferred back to the Ukrainian SSR in order to serve: "the common interests of the Soviet state for geographic and economic considerations" (Wilson Center 2020). The decision did not have a strategic effect immediately because Ukraine was part of the USSR at the time, it was 60 years later, under President Vladimir Putin, in the context of civil unrest that the illegal annexation of the Crimean peninsula to the Russian Federation occurred. Russia was gaining back its naval bases, key strategic military positions, a naval academy, and, most importantly from a geopolitical standpoint, access to the Black Sea. The paper focuses on the Romanian perspective, so what exactly did the annexation of Crimea mean for Romania and therefore to NATO? Romania has a longstanding tense relationship with the Russian Federation and it had a special relationship with its predecessor, the Soviet Union. Deep patterns of conflict can be identified: both direct conflict as well as indirect, in the shape of campaigns of influence, disinformation, and, of course, the issue of the Republic of Moldova, the Romanian territory lost by Romania to Soviets in 1940.

The Romanian American Strategic Partnership as well as membership in the North Atlantic Alliance are the strongest anchors of Romain security and defence architecture especially because of the Russian threat as perceived, rightfully, by Romania. Romania has consistently been an active and very visible member of NATO overall and especially in the Black Sea Space. The actions by the Russian Federation warrant the Romanian position: the illegal annexation of Crimes in 2014, the non conformation to international law, the very vocal critique by the Kremlin of the Liberal World Order which Romania is a very strong proponent of and willing participant in, the numerous frozen conflicts that are protracted by the Russian Federation directly or indirectly with the clear aim to destabilize the region economically as well as politically. All these facts make Romania a key regional security actor. The Romanian armed forces have hosted and participated in NATO exercises on a regular basis. At the Warsaw 
summit in 2016 NATO agreed to set up a Romanian-Bulgarian multinational brigade. NATO Secretary General Jens Stoltenberg declared at the time that the brigade aim is to be in charge of keeping the balance in southeastern Europe and the Black Sea region (NATO 2016).

US led Saber Guardian was first conducted in Romania in 2013. It started out as an annual exercise rotating between Bulgaria, Romania and Ukraine until 2017 when it became biannual (US Army Europe, 2019). The two "major objectives have stayed consistent through each iteration: increasing interoperability among participating nation militaries and strengthening regional security cooperation" (US Army Europe 2019). NATO's Enhanced Forward Presence has two main components: Enhanced Forward Presence (EFP) which focuses on the Baltic States and Poland and Tailored Forward Presence (TFP) focused on Romania and Bulgaria. Romania is a contributor to both components demonstrating commitment to the collective defence concept not just to its own security. Tailored Forward Presence has a stated focus of establishing and consolidating "defensive capabilities in the Black Sea region with the Multi-national Divisional Headquarters South East (HQ MND-SE) in Bucharest since becoming operational in the summer of 2017"' (Shape, NATO 2018).

NATO is often looked at as the solution to all conflicts and threats in Europe, practitioners of the armed forces however will be the first to note that Article 5 alone cannot guarantee a defence. In the case of the Black Sea any sort of aggression against Romania could indeed lead to at the activation of Article 5, but would take time and consensus. Romania needs to be ready for an attack even if just for deterrence purposes. By engaging deeper in with the EU in the PeSCo framework, Romania can benefit and improve interoperability and mobility of troops.

\subsection{Interoperability and Crisis Readiness in the Black Sea}

The 2014 illegal annexation of Crimea has served as a wakeup call for the international community, including those European countries who were not yet convinced that the East is indeed vulnerable. Wakeup call because it generated an actual response unlike the 2008 Georgian War. As recently as June 2020 The 
EU Council announced the decision to renew the sanctions introduced in response to the illegal annexation of Crimea and Sevastopol by the Russian Federation until 23 June 2021. The sanctions currently in place include: "prohibitions targeting the imports of products originating in Crimea or Sevastopol into the EU, and infrastructural or financial investments and tourism services in Crimea or Sevastopol" (EU Council 2020). These restrictive measures also affect transport telecommunications and energy sectors or for the prospection, exploration and production of oil, gas and mineral resources are also subject to EU restrictions" (EU Council 2020).

As previously discussed, the NATO response has taken shape both militarily and politically: progressive increase in rotational presence in the Black Sea, the establishment of the Multinational Division in Bucharest in 2015, political pressure in the form of consistent declarations. The Northern half of the Eastern Flank has received far more attention from the EU both militarily and economically than the Southern half. Paradoxically, it is in the Greater Black Sea Area that the stakes are far higher and the environment far more auspicious to Russian influence and where Russia has obtained its concrete, major territorial, material gain: the annexation of the Crimean peninsula and through this the reacquisition of Sevastopol Naval Base. The Black Sea region is of vital importance to Romanian security: the region is present in all official security and defense documents, including the 2016 Military Strategy of Romania, the 2017 White Paper on Defense and the National Defense Strategy 2015-2019, the National Defense Strategy 2020 to 2024. NATO also has a visible presence in the Black Sea, so do the United States. Although the Black Sea area in itself may not be at the top of the American priority list, the Missile shield at Deveselu Base and the American troops stationed in Romania are a testimony to US commitment. Politically, the region has been on the receiving end of American support. PeSCo projects could very well work as the European framework in the infrastructure and logistics sector as much as other projects such as for example the Three Seas Initiative. The Three Seas Initiative " a flexible political platform, at Presidential level" was launched in 2015. The Initiative, which "creates a political platform to promote connectivity among nations in Central and Eastern Europe by supporting infrastructure, energy, and digital interconnectivity 
projects" (Wemer, 2019) could create more synergy in military cooperation as well. The two initiatives could also work towards bridging differences in prioritization between NATO, the current European security provider, and the European Union, who expressed its intent on becoming more autonomous in the defence sector. The American support materialized concretely earlier this year when at the Munich Security Conference, US Secretary of State Mike Pompeo announced:

"The West is winning, we are collectively winning, we are doing it together, and as a brand new statement today of our support for sovereignty, prosperity, and energy independence for our European friends, today I want to announce that through the International Development Finance Corporation and with the support or our United States Congress, we intend to provide up to one billion dollars in financing to Central and Eastern European countries of the Three Seas Initiative," (US Department of State 2020)

Former Romanian defence minister Ioan Mircea Pascu alerted to the difference in prioritization back in 2007 by outlining that the Eastern member states would arguably favor a tighter cooperation between NATO and EU, also pointing out the fact that this could serve as the perfect opportunity to allow each institution "to do what it does best" (Pascu 2007).

NATO regularly conducts naval exercises in the Black Sea. Rear Admiral Paolo Fantoni, Commander of SNMG2 emphasized at the end of a recent exercise the importance of strengthening capabilities and deepening interoperability: "Today's exercise has given both the NATO Group and the Romanian Navy and Air Force an invaluable opportunity. It allowed the participants to maintain and strengthen their capabilities and demonstrated how we can integrate readily with assets not belonging permanently to the force" (NATO 2020). The admiral confirmed that the Black Sea is " a very sensitive area for the Alliance". This can be further enhanced by PeSCo projects such as Military Mobility.

In March 2017 Romania hosted Exercise Poseidon "The goal of the naval exercise was to practice NATO tactics, techniques and standard procedures, and 
to increase interoperability" (NATO 2017) In May 2018 Romania led NATO exercise with naval assets from seven Allied States and NATO's Standing Maritime Group Two trained maritime capabilities, anti-submarine procedures and combat proficiency in the Black Sea (Ibid). All NATO exercises could only benefit from PeSCo projects such as the Military Mobility project which Romania participates in.

Security and military operations are not always completely compatible with political goals such as "europeanization" however, they are also not mutually exclusive.

\section{CONCLUSIONS}

Romania today is a key security actor in the Black Sea space. Romanian leadership is aware of this and the security and defence architecture reflects it, unfortunately, funding shortages and internal vulnerabilities like very outdated infrastructure and a long track record of corruption impede the application of these plans sometimes. Strategically, Romanian view is built upon three pillars: the Romanian American Strategic Partnership, the membership in NATO and the EU membership. Due to the shifts that are underway in the international system, these pillars have different effects on the security of Romania. The first one, as reiterated by President Iohannis on numerous occasions, remains the central relationship. In relation tot he global context, bilateral agreements with the US guarantee Romania American support in case of a territorial or nonkinetic aggression.

From a Romanian point of view, the third pillar, the EU could be most leveraged defence wise in the PeSCo framewok. Romanian perspective on PeSCo is positive, capability and interoperability driven, motivated by the aim for deepening EU-NATO integration. PeSCo serves as a tool in the arsenal of EU instruments that can facilitate cohesion and synergy within the transatlantic community as well as a catalyst for improving infrastructure. The Permanent Structured Cooperation Framework could potentially lead to a better strategic 
approach in key EU and NATO spaces, such as the Black Sea. PeSCo can also facilitate educational interoperability and training coordination, therefore Romania is an active participant in projects meant to enhance these sectors. Finally, in Romania, at least so far, PeSCo did not serve ideological purposes, but purely military and logistical ones. For Romania, European strategic autonomy does not exclude collaboration with the Atlantic partners, it means that systems and personnel will be better integrated and division of labour will take pace both during peacetime and in the case of a conflict. On a regional and global level PeSCo, just like initiatives such as Three Seas offer an opportunity to strengthen the economies of US allies as well as to work through any temporary political differences within the Euro Atlantic coalition.

A continuation of an appropriate strategic approach as well as allocating sufficient resources could aid Romania in improving its security and defence sector. It remains to be seen how implementation will be continuing, especially in the context of the current global health crisis. Furthermore, the Romanian government has to resolve internal vulnerabilities such as a very weak health system, outdated infrastructure and, still, concerns about corruption.

Finally, the Permanent Structured Command framework could serve as a great tool towards an overarching goal of European cohesion which in the context of the global transformations is invaluable. After the UK voted on leaving the Union, after several EU member states elected populist governments which have an agenda of at most dismantling and at least destabilizing the EU, after the global health crisis exposed all the flaws in the international system herein accelerating changes in the structure, Europe more than ever needs to employ mechanisms that can ad in driving unity and proper crisis management. It is invaluable, especially in uncertain times like the ones we are experiencing today to maintain a united front, especially in the security and defence realm. The Romanian strategic documents reflect this attitude, and this point is consistently reiterated by the Romanian president on his official visits, in his declarations and public statements. Romania sees the value in the complementarity of the NATO-EU relationship and does not propagate strategic autonomy as a divisive tool, but a unifying aid that improves the interoperability of transatlantic armed forces. 
This year's Munich Security Conference was themed Westlessness mirroring tensions in the Euro Atlantic relations. Strategic approaches focused on capabilities and resources are quintessential in bridging any differences and in leading to a resolve. If values can be debated and interests can be selfish, security, defence and stability are clear common denominators for both America and Europe. Furthermore, on the security and defence agenda, resources, capabilities, logistics, they all serve their purpose better by being streamlined. The Romanian strategic view, deeply marked by both its history and geographical position, serves as a reasonable example of how synergy can indeed be facilitated and realistically achieved.

\section{REFERENCES}

- Albright, Madeleine K. 1998. "Statement to the North Atlantic Council". Brussels, Belgium, December 8. As released by the Office of the Spokesman U.S. Department of State. https://19972001.state.gov/statements/1998/981208.html

- Billon-Galland, Alice, and Martin Quencez. 2017. Report. German Marshall Fund of the United States. Accessed October 15, 2020. http://www.jstor.org/stable/resrep18774.

- Bilanț MApN. 2020. Agerpres. bucharest.2019.https://www.agerpres.ro/politica/2020/02/25/bilantmapn-nicolae-ciuca-prezenta-nato-in-regiunea-marii-negre-este-unimperativ-strategic -454804 .

- Buzan, Barry. "New Patterns of Global Security in the Twenty First Century". International Affairs. Vol. 67, No. 3 (Jul., 1991): 431-451. Blackwell Publishing on behalf of the Royal Institute of International Affairs.

- Buzan, Barry. 1983. "People, States and Fear, The National Security Problem in International Relations". United Kingdom: Wheatsheaf Books LTD.

- Clausewitz, Carl von. 1976. On War. Princeton, New Jersey: University Press. 
- Consiliul Suprem de Apărare a Țării-CSAT. https://csat.presidency.ro

- Deutsche Welle Documentary "Pipeline Politics: Putin, Europe and the Nord Stream 2: How a gas pipeline between Russia and Germany divides NATO and splits Europe".

- European Parliament. 2016. "Common Security and Defence Policy (CSDP)". https://www.europarl.europa.eu/ftu/pdf/en/FTU_5.1.2.pdf.

- Geoană, Mircea, NATO Deputy Secretary General, Speech at the "NATO Engages: Innovating the Alliance" conference, London. December 3, 2019, https://www.nato.int/cps/en/natohq/opinions_171551.htm?selectedLoca le $=$ fr.

- Keohane, Robert O. 1984. After Hegemony: Cooperation and Discord in the World Political Economy. Princeton, NJ: Princeton University Press.

- McLeary, Paul. 2019. "State, DoD Letter Warns European Union to Open Defense Contracts, Or Else". Reuters. https:// breakingdefense.com/2019/05/state-dod-letter-warns-europeanunion-to-open-defense-contracts-or-else/.

- Mearsheimer John J.2007. "Structural Realism," in Timothy Dunne, Milja Kurki, Steve Smith. International Relations Theories: Discipline and Diversity. Oxford University Press.

- Mearsheimer, John J.2001. The Tragedy of Great Power Politics. New York: W. W. Norton \& Company.

- Ministerul Apărării Naționale- MApN. 2020. https:/ / www.mapn.ro

- Munich Security Report 2020. https://securityconference.org/publikationen/munich-security-report2020/.

- NATO Force Integration Unit. 2020. http://www.nfiu.ro

- Permanent Structured Cooperation (PESCO). 2020. https://pesco.europa.eu

- President Klaus Iohannis. 2019. "Address by the President of Romania, Mr. Klaus Iohannis, at the Munich Security Conference". Presidency. https://www.presidency.ro/ro/presa/securitate-nationala-siaparare/alocutiunea-presedintelui-romaniei-domnul-klaus-iohannis- 
sustinuta-cu-prilejul-participarii-la-cea-de-a-55-a-conferinta-pentrusecuritate-de-la-munchen

- Presidency of Romania. 2020. "Strategia Națională de Apărare a Țării pentru perioada 2020-2024, Impreuna, pentru o Romanie sigura ssi prosperaintr-o lume marcata de noi provocari". Pesidency. https://www.presidency.ro/files/userfiles/Documente/Strategia_Nationa la_de_Aparare_a_Tarii_2020_2024.pdf.

- Presidency of Romania. "Strategia Națională de Apărare a Ţării pentru 2015 2019". 2015.

Presidency. https://www.presidency.ro/files/userfiles/Strategia_Nationala_de_Apara re_a_Tarii_1.pdf.

- Republic of Turkey Ministry of Foreign Affairs. "Turkey- NATO Together for Peace and Security Since 60 Years". http://www.mfa.gov.tr/turkeynato-together-for-peace-and-security-since60-years.en.mfa

- Romanian National Defense Ministry. 2016. "Cartea Alba a Apararii". MApN. https://www.mapn.ro/legislatie/documente/carta_alba.pdf

- Smith, Adam. 2007. An Inquiry into the Nature and Causes of the Wealth of Nations. MetaLibri.

- Thomson Reuter Staff. 2018. “Dutch PM Rutte: NATO remains cornerstone of European defense". Reuters. https://www.reuters.com/article/usnetherlands-nato/dutch- pm-rutte-nato-remains-cornerstone-of-europeandefense-idUSKCN1NL1RH.

- Thucydides. 2009. The Peloponnesian War. Oxford World's Classics. Oxford: Oxford University Press.

- US Department of State. 2020. "The West Is Winning, Speech by Michael R. Pompeo, Secretary of State, Munich, Germany, Munich Security Conference, February 15, 2020". https://translations.state.gov/2020/02/15/the-west-iswinning/.

- US Embassy, Romania. 2020. “United States Ballistic Missile Defense Site at Deveselu Air Base in Romania". https://ro.usembassy.gov/ourrelationship/implementing-missile-defense-europe/united-states-ballisticmissile-defense-site-at-deveselu-air-base-in-romania/. 
- US Joint Chiefs of Staff. 2018. "Joint Doctrine Note 1-18". https://www.jcs.mil/Portals/36/Documents/Doctrine/jdn_jg/jdn1_18.pd $\mathrm{f}$ ?ver=2018-04-25-150439-540

- Walt, Stephen M. 1985. "Alliance Formation and the Balance of World Power". In International Security 9 (4): 3-43

- Walt, Syephen M. 1987. The Origins of Alliances. Ithaca, NY: Cornell University Press.

- Waltz, Kenneth. 1979. Theory of International Politics. Mass: Addison-Wesley Publishing Company.

- Waltz, Kenneth N. 1959. Man, The State, and War: A Theoretical Analysis. Columbia University Press: New York.

- White House. 2019. "Joint Statement from President of the United States Donald J. Trump and President of Romania Klaus Iohannis". https://www.whitehouse.gov/briefings-statements/joint-statementpresident-united-states-donald-j-trump-president-romania-klausiohannis/.

- White House Staff. 2017. "President Donald J. Trump Announces a National Security Strategy to Advance America's Interests". https://www.whitehouse.gov/briefings-statements/president-donald-jtrump-announces-national-security-strategy-advance-americas-interests/.

- Wemer, David A. 2019. "The Three Seas Initiative explained". Atlantic Council. https://www.atlanticcouncil.org/blogs/new-atlanticist/the-threeseas-initiative-explained-2/. 